\title{
Purification and Characterization of Endo- $\beta-1$, 4-Glucanase from Local Isolate Trichoderma Ouroviride
}

\author{
Selmihan Şahin, İsmail Ozmen, and Hacı H. Bıyık
}

\begin{abstract}
Cellulose is major source of plant biomass and $\beta-1,4-$ glucosidic bonds in its structure are hydrolyzed by cellulases. These enzymes can be produced by microorganisms including fungi, bacteria and actinomycetes and are used today for the industrial applications in the pulp and paper, food and textile industries and in the conversion of plant biomass materials into industrially useful products such as sugars and bio-ethanol. The cost of production and low yields of these enzymes are the major problems for industrial applications. For this reason, there is a requirement that new microbial enzyme sources are investigated with the aim of improving cellulase production. In this study, the endo- $\beta-1,4$ glucanase from local isolate Trichoderma ouroviride was produced in submerged fermentation using carboxymethylcellulose as a carbon source. The enzyme was purified by ammonium sulphate precipitation and gel chromatography with 7,2 -fold in a yield of $4,1 \%$. The optimal $\mathrm{pH}$ and temperature of purified enzyme was determined. In conclusion, the optimal $\mathrm{pH}$ and temperature for hydrolytic activity toward $\mathrm{CMC}$ was $\mathbf{5 0}^{\circ} \mathrm{C}$ and pH 5, 0, respectively. It was understood that the purified enzyme has adequate activity and properties for industrial applications.
\end{abstract}

Index Terms-Cellulase, characterization, purification, trichoderma ouroviride.

\section{INTRODUCTION}

Cellulose is the most abundant organic polymer on earth [1]. A variety of fungi and bacteria convert this polymer into soluble sugar through a group of cellulase enzymes [2]. Trichoderma species are known as the highest cellulase producer and mostly used in commercial cellulase production. One of these is Trichoderma reesei that produces at least two exoglucanases (CBHI and CBHII), five endoglucanases (EGI, EGII, EGIII, EGIV, and EGV), and two $\beta$-glycosidase [3], [4]. Cellulases hydrolyze $\beta-1,4-$ glycosidic bond in the cellulose structure and operate as a multicomponent enzyme system which consists of three classes of enzyme; Endoglucanases (endo- $\beta$-1,4-glucanase, CMCase, EC 3.2.1.4), cellobiohydrolases (exoglucanase, avicelase, EC 3.2.1.91) and $\beta$-glucosidase (cellobiase, EC 3.2.1.21) [5].

The first two enzymes are called as 'real cellulase' and produce cellobiose and glucose by acting directly on cellulose. The cellobiose is then hydrolyzed into glucose by $\beta$-glucosidase [5], [6].

Endoglucanases cleave the internal glycosidic bonds of

Manuscript received November 26, 2012; revised January 10, 2013.

S. Şahin and İ. Ozmen are with the Suleyman Demirel University, Faculty of Arts and Science, Chemistry Department, Turkey (e-mail: selmihansahin@sdu.edu.tr, ismailozmen@sdu.edu.tr ).

Hacı H. Biyık is with the Adnan Menderes University, Faculty of Arts and Science, Biology Department, Turkey (e-mail: hbiyik@adu.edu.tr ). cellulose chains and act synergistically with exoglucanase and $\beta$-glucosidase during the hyrolysis of crystalline cellulose. Also, endoglucanases are used in increasing the yield of fruit juices, beer filtration, and oil extraction, improving the nutritive quality of bakery products and animal feed, and enhancing the brightness, smoothness, and over all quality of cellulosic garments. Therefore, new fungal sources and properties (optimal $\mathrm{pH}$ and temperature) of EG must be investigated [1].

The main purpose of this study was to investigate the procedures of enzyme purification and the biochemical properties of the endo- $\beta-1,4$-glucanase produced by native $T$. ouroviride.

\section{MATERIALS AND METHODS}

\section{A. Materials}

Carboxymethylcellulose Sodium Salt was obtained from Alfa Aesar, Sephadex G-100 was obtained from Sigma Chemicals Co. Ltd. Other chemical reagents were analytical grade. The strain of Trichoderma ouroviride was isolated by H. Halil Biyık.

\section{B. Optimization of Endo- $\beta$-1, 4-Glucanase Production Conditions}

İnitially, culvitation for EG production was studied at two different pHs (5 and 7) and temperatures $\left(30^{\circ} \mathrm{C}\right.$ and $\left.50^{\circ} \mathrm{C}\right)$. The enzyme activity was monitored from second day until sixth day of cultivation. It was determined optimum $\mathrm{pH}$ and temperature for EG production.

\section{Endo- $\beta$-1, 4-Glucanase Production}

The organism was maintained on malt extract agar (MEA) slant at $4^{\circ} \mathrm{C}$ and sub-cultured on MEA plates, then, incubated at $30^{\circ} \mathrm{C}$ for 7 days to obtain the inoculum used in this study.

It was cultured Trichoderma ouroviride in a modified Mandel and Weber (1969) medium for cellulase production [7]. Chemical composition of the medium is as follows $(\mathrm{g} / \mathrm{L})$; $\mathrm{KH}_{2} \mathrm{PO}_{4}: 2,\left(\mathrm{NH}_{4}\right)_{2} \mathrm{SO}_{4}: 1,4$, urea: $0,3, \mathrm{MgSO}_{4} .7 \mathrm{H}_{2} \mathrm{O}: 0,14$, $\mathrm{CaCl}_{2}$ : 0,3 and mg/L; $\mathrm{FeSO}_{4} \cdot 7 \mathrm{H}_{2} \mathrm{O}: 5, \mathrm{MnSO}_{4} \cdot \mathrm{H}_{2} \mathrm{O}: 1,56$, $\mathrm{ZnSO}_{4} \cdot 7 \mathrm{H}_{2} \mathrm{O}: 1,4, \mathrm{CoCl}_{2}: 2.1 \%$ (w/v) CMC, used as a carbon source. After 5 days incubation at $30^{\circ} \mathrm{C}$ and $\mathrm{pH} 5$ with stirring, the culture broth was centrifuged at $8000 \mathrm{rpm}$ for 30 min to remove the cells. The supernatant were used for further EG purification.

\section{Determination of Enzyme Activity}

The endo- $\beta$-1,4-glucanase activity was measured by using 3,5 Dinitrosalicylic acid (DNS) method [8]. The amount of reducing sugars liberated from CMC solubilized in $50 \mathrm{mM}$ 
citrate buffer ( $\mathrm{pH} 5)$ by the enzyme was determined in this assay. The enzyme and $1 \%(\mathrm{w} / \mathrm{v}) \mathrm{CMC}$ solution were incubated for $30 \mathrm{~min}$ at $50^{\circ} \mathrm{C}$. The reaction was stopped by addition of DNS solution. After this step, the samples were boiled for $5 \mathrm{~min}$, cooled in ice for color stabilization. The optical density was measured at $540 \mathrm{~nm}$. The cellulase activity was determined by using a calibration curve for glucose. One unit of enzyme activity was defined as the amount of enzyme that released $1 \mu \mathrm{mol}$ of glucose per minute.

\section{E. Protein Estimation}

Protein concentration was determined by using the Lowry method. BSA was used as standart protein [9].

\section{F. Purification of Endo- $\beta$-1, 4- Glucanase}

All purification steps were carried out at room temperature. The culture supernatant was precipitated by $60-80 \%$ saturation of ammonium sulphate. The precipitate was resuspended in minimal volume of $50 \mathrm{mM}$ citrate buffer $(\mathrm{pH}$ 5). The solution was dialyzed against the same buffer for $20 \mathrm{~h}$ with two times changes. The dialyzed fraction was loaded onto pre-equilibrated with $50 \mathrm{mM}$ citrate buffer $(\mathrm{pH} 5)$ Sephadex G-100 $(1 \times 30 \mathrm{~cm})$. The fractions showed maximum enzyme activity were pooled [10].

\section{G. Studies of Optimum pH, Temperature and Thermal Stability}

The buffers used in the assay were $50 \mathrm{mM}$ citrate buffers ( $\mathrm{pH}$ 4.0-6.0) and phosphate buffers ( $\mathrm{pH}$ 6.0-9.0). To find the optimum $\mathrm{pH}$, the enzyme was incubated with $1 \% \mathrm{CMC}(\mathrm{w} / \mathrm{v})$ dissolved in the assay buffers with $\mathrm{pH}$ varying from 4.0 to 9.0 for $30 \mathrm{~min}$ at $50^{\circ} \mathrm{C}$.

The optimum temperature for CMCase activity was determined by incubating the enzyme with $1 \% \mathrm{CMC}(\mathrm{w} / \mathrm{v}$, dissolved in $50 \mathrm{mM}$ citrate buffer, $\mathrm{pH} \mathrm{5.0)}$ ) for $30 \mathrm{~min}$ in the temperature range varying from $30^{\circ} \mathrm{C}$ to $70^{\circ} \mathrm{C}$.
Thermal stability studies were carried out by incubating the enzyme and \% $1 \mathrm{w} / \mathrm{v}$ CMC solution as activity assay at the $50^{\circ} \mathrm{C}$ for various durations (between $40 \mathrm{~min}-72 \mathrm{~h}$ ). Then, the amount of released reducing sugars was determined by DNS method.

\section{RESULTS AND DISCUSSION}

\section{A. Optimization of Endo- $\beta$-1, 4-Glucanase Production Conditions}

Production of cellulases has been intensively investigated because of their different industrial applications although cellulases are difficultly purified from fungus.

In this study, $T$. ouroviride was newly isolated from hot water spring, Aydın, Turkiye. According to cultivation studies, the ideal time for the EG production is on the fifth day. After this time period, a decrease in productivity was observed. While the activity was detected at $\mathrm{pH} 5$, at $\mathrm{pH} 7$ wasn't. The enzyme activity reached a maximum value on the fifth day at $\mathrm{pH}$ 5. Also, the growth wasn't detected at $50^{\circ} \mathrm{C}$, but it is obtained at $30^{\circ} \mathrm{C}$. In next studies, cellulase production was studied at $30^{\circ} \mathrm{C}$ for 5 days.

\section{B. Purification of Endo- $\beta$-1, 4- Glucanase}

The results of a purification scheme are given in Table I. To purify the enzyme, $T$. ouroviride were incubated in broth culture with $1 \%(\mathrm{w} / \mathrm{v}) \mathrm{CMC}$ as a carbon source to induce the synthesis of the CMCase. The culture supernatant of $T$. ouroviride contained extremely low level of EG activity. The enzyme first concentrated by ammonium sulphate precipitation and then dialyzed to remove salt. Concentrated enzyme was applied on gel filtration chromatography. The isolation of the endoglucanase resulted in approximately 6 -fold purification based on the protein content of the original crude extract. The specific activity of enzyme was $5.94 \mathrm{Umg}^{-1}$ and a yield of 3,5\%. The purification procedure is summarized in Table I.

TABLE I: SUMMARY OF THE PURIFICATION OF ENDO-B-1, 4-GLUCANASE FROM T. OUROVIRIDE
\begin{tabular}{|l|c|c|c|c|c|c|}
\hline $\begin{array}{l}\text { Purification } \\
\text { Step }\end{array}$ & $\begin{array}{c}\text { Volume } \\
(\mathrm{mL})\end{array}$ & $\begin{array}{c}\text { Total } \\
\text { Protein } \\
(\mathrm{mg})\end{array}$ & $\begin{array}{c}\text { Total } \\
\text { Activity } \\
(\mathrm{EU})\end{array}$ & $\begin{array}{c}\text { Specific } \\
\text { Activity } \\
(\mathrm{U} / \mathrm{mg})\end{array}$ & $\begin{array}{c}\text { Yield } \\
(\%)\end{array}$ & $\begin{array}{c}\text { Purification. } \\
\text { fold }\end{array}$ \\
\hline $\begin{array}{l}\text { Crude } \\
\text { extract }\end{array}$ & 500 & 225 & 215 & 0,95 & 100 & 1 \\
\hline $\begin{array}{l}\text { Ammonium } \\
\text { sulfate } \\
\text { Precipitation } \\
(60-80 \%)\end{array}$ & 8,5 & 3 & 9,2 & 3,1 & 4,3 & 3,3 \\
\hline Gel Fitration & 7 & 1,3 & 8,9 & 6,85 & 4,1 & 7,2 \\
\hline
\end{tabular}

\section{A. Optimum pH, Temperature and Thermal Stability}

At $\mathrm{pH}$ 5, EG activities were measured at various temperatures from $30^{\circ} \mathrm{C}$ until $70^{\circ} \mathrm{C}$ to determine the optimal temperature. The results showed that the optimal temperature was $50^{\circ} \mathrm{C}$ [Fig. 1].

At $50{ }^{\circ} \mathrm{C}$, the effect of $\mathrm{pH}$ on $\mathrm{EG}$ activity for hydrolysis of CMC was determined. T. ouroviride EG exhibited optimal activity at pH 5 [Fig. 2].

Thermal stability of the endoglucanase was studied by incubating at $50^{\circ} \mathrm{C}$ for different times ranging from $40 \mathrm{~min}$ to
$72 \mathrm{~h}$ (three days) [Fig. 3]. The enzyme sustained its activity after $72 \mathrm{~h}$ of incubation. It has seen from other studies that the optimal temperatures for fungi EG activities are usually between 50 and $60{ }^{\circ} \mathrm{C}$ and stable up to $50-55^{\circ} \mathrm{C}$ [11]. In a previous study, endoglucanase purified from Clostridium thermocellum has exhibited activity for lengths of time up to $48 \mathrm{~h}$ at $60^{\circ} \mathrm{C}$ [13]. It has been understood that EG of this fungus has adequate activity and stability for industrial process.

The previous studies showed that optimum temperature and $\mathrm{pH}$ for cellulase obtained from Aspergillus glaucus XC9, 
Pseudomonas fluorescens, Clostridium thermocellum and Aspergillus terreus DSM 826 were $50^{\circ} \mathrm{C}$ and $\mathrm{pH} 4,35^{\circ} \mathrm{C}$ and $\mathrm{pH} 7,70^{\circ} \mathrm{C}$ and $\mathrm{pH} 7$, and $50^{\circ} \mathrm{C}$ and $\mathrm{pH} 4.8$, respectively. In this study, we recorded the similar results [11] - [14].

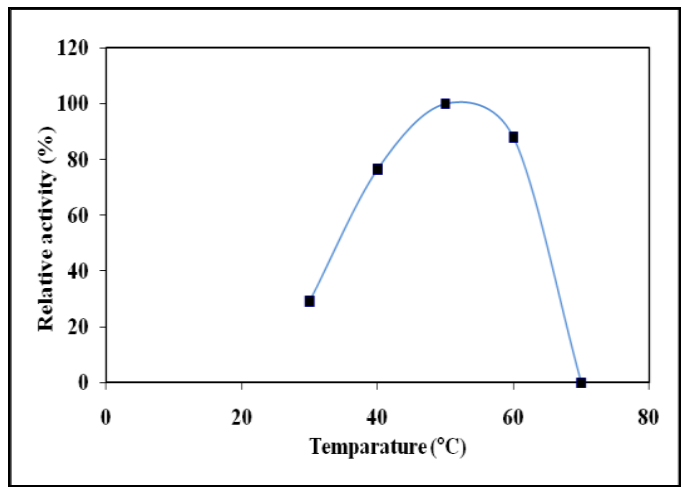

Fig. 1. Effect of temparature on purified cellulase from T. ouroviride. Enzyme activity was determined by incubating the enzyme in citrate buffer (50 mM pH 5.0) containing $1 \%(\mathrm{w} / \mathrm{v})$ carboxymethylcellulose at respective temperature and assaying the reducing sugar released. The $100 \%$ enzyme activity was the maximum enzyme activity in citrate buffer $(50 \mathrm{mM}, \mathrm{pH} 5.0)$ between 30 and $80^{\circ} \mathrm{C}$.

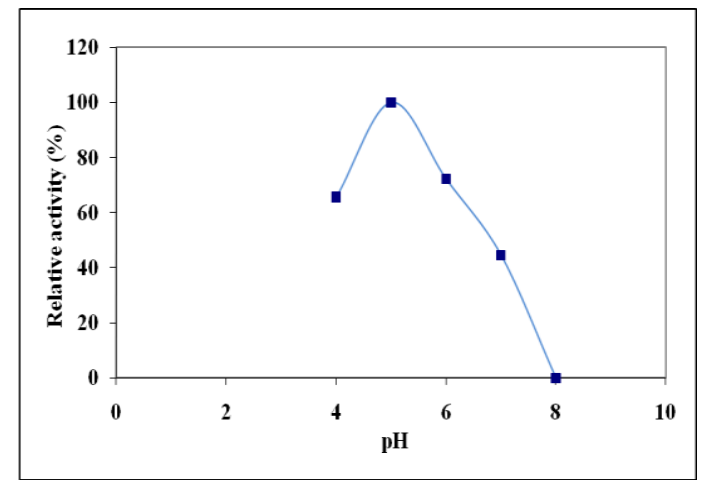

Fig. 2. The effect of $\mathrm{pH}$ on EG activity, the enzyme activity was assayed at $50^{\circ} \mathrm{C}$.

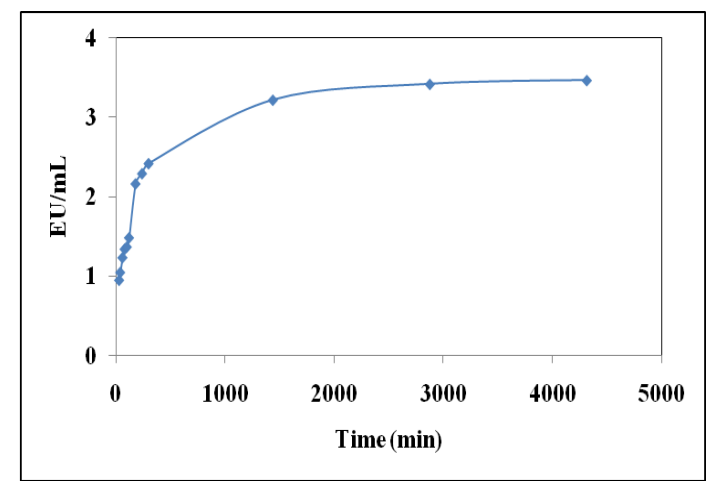

Fig. 3. Thermal stability of the enzyme at the $50^{\circ} \mathrm{C}$ for various durations (from $40 \mathrm{~min}$ to $72 \mathrm{~h}$ ).

Acharya and coworkers isolated A. niger from soil near paper manufacturing industry, Sadra, Gandhinagar, Gujarat, India. According to this study, enzyme activity is determined as $0,0962 \mathrm{EU} / \mathrm{mL}$, after $96 \mathrm{~h}$ incubation on sawdust of isolated fungus [15].

Tao et al. isolated Aspergillus glaucus XC9 from mildew maize cob. This isolated fungus produced cellulase on sugarcane baggase for 4 days. Specific activity of cellulase in the culture filtrate was found 0,55 EU/mg [11].

Mansfield and coworkers produced endoglucanase from
Gloeophyllum sepiarium and Gloeophyllum trabeum and EG activities were $410,360 \mathrm{nkat} / \mathrm{ml}$ in the culture filtrate, respectively [16].

In this study, when EG activity produced from local isolate of $T$. ouroviride compared with studies mentioned above, it was understood that the novel fungus produced high amount EG activity.

\section{CONCLUSION}

In this work was presented purification and characterization of endo- $\beta-1$, 4-glucanase from newly isolated T. ouroviride from hot water spring, Aydın, Turkiye, which would have a wider application in the industrial applications with acidic $\mathrm{pH}$ optimum and high thermostability.

In addition, the cultural conditions were optimized for higher yield of cellulase enzyme. Because activity of EG obtained from $T$. ouroviride was high at determined culture conditions, it is said that local isolate $T$. ouroviride can be used for commercial cellulase production.

\section{APPENDIX}

CMCase; carboxymethylcellulase,

$\mathrm{CBH}$ cellobiohydrolase, EG; endoglucanase, HEC; hydroxyethylcellulose.

\section{REFERENCES}

[1] G. S. Naika, P. Kaul, and V. Prakash, "Purification and characterization of a new endoglucanase from Aspergillus aculeatus," J. Agric. Food Chem., vol. 55, pp. 7566-7572, August 2007.

[2] M. Sohail, R. Siddiqi, A. Ahmad, and S. A. Khan, "Cellulase production from Aspergillus niger MS82: effect of temperature and pH," New Biotechnology, vol. 25, pp. 6, September 2009.

[3] M. Nogawa, H. Takahashi, A. Kashiwagi, K. Ohshima, H. Okada, and Y. Morikawa, "Purification and Characterization of Exo- $\beta$-D-Glucosaminidase from a Cellulolytic Fungus, Trichoderma reesei PC-3-7," Applied And Environmental Microbiology, vol. 64, pp. 890-895, Mar.1998.

[4] L. R. Lynd, P. J. Weimer, W. H. Vanzyl, and I. S. Pretorius, "Microbial cellulose utilization: Fundamentals and biotechnology," Microbiology and Molecular Biology Rewievs, vol. 66, no. 3, pp.506-577, September 2002.

[5] A. Dincer and A.Telefoncu, "Improving the stability of cellulase by immobilization on modified polyvinyl alcohol coated chitosan beads," Journal of Molecular Catalysis B: Enzymatic, vol. 45, no. 5, pp. 10-14, Nov. 2006.

[6] N. Andersen, "Enzymatic hydrolysis of cellulose," Ph.D. dissertation, Dept. Chemical Eng., Technical University of Denmark, Copenhagen, Denmark, 2007.

[7] M. Mandels and J. Weber, "The production of cellulases," Advances in Chemistry, vol. 95, pp. 391-414, June 1969.

[8] T. K. Ghose, "Measurement of cellulase activities," Pure \& App. Chem., vol. 59, no. 2, pp. 257-268, 1987.

[9] O. H. Lowry, N. J. Rosebrough, A. L. Farr, and R. J. Randall, "Protein measurement with the Folin phenol reagent," J. Biol. Chem., vol. 193, pp. $265-275,1951$.

[10] S. O. Kotchoni, E. W. Gachomo, B. O. Omafuvbe, and O. O. Shonukan, "Purification and biochemical characterization of carboxymethyl cellulase (CMCase) from a catabolite repression insensitive mutant of Bacillus pumilus," International journal of Agriculture and Biology, vol. 8, no. 2, pp. 286-292, 2006.

[11] Y. Tao, X. Zhu, J. Huang, S. Ma, X Wu, M. Long, and Q. Chen, "Purification and properties of endoglucanase from a sugarcane bagasse hydrolyzing strain, Aspergillus glaucus XC9," J. Agric. Food Chem., vol. 58, pp. 6126-6130, 2010.

[12] M. K. Bakare, I. O. Adewale, A. Ajayi, and O. O. Shonukan, "Purification and characterization of cellulase from thewild-type and 
two improved mutants of Pseudomonas fluorescens," African Journal of Biotechnology, vol. 4, no. 9, pp. 898-904, September 2005.

[13] M. P. M. Romaniec, T. Ursula Fauth, T. Kobayashi, N. S. Huskisson, T. Patrick J. Barkert, and A. L. Demain, Purification and Characterization of a New Endoglucanase from Clostridium Thermocellum Biochem, vol. 283, 69-73, 1992.

[14] A. M. Elshafei, M. M. Hassan, B. M. Haroun, O. M. A. Fatah, H. M. Atta, and A. M. Othman, "Purification and properties of an endoglucanase of Aspergillus terreus DSM 826," Journal of Basic Microbiology, vol. 49, pp. 426-432, 2009.

[15] P. B. Acharya1, D. K. Acharya1, and H. A. Modi, "Purification and properties of endoglucanase from a sugar cane bagasse hydrolyzing strain, aspergillus glaucus XC9," African Journal of Biotechnology, vol. 7, no. 22, pp. 4147-4152, November, 2008.

[16] S. D. Mansfield, J. N. Saddler, and G. M. Gu"bitz, "Characterization of endoglucanases from the brown rot fungi Gloeophyllum sepiarium and Gloeophyllum trabeum," Enzyme and Microbial Technology, vol. 23, pp. 133-140, 1998

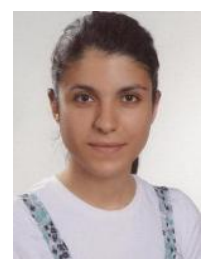

Selmihan Sahin was born in June, 1990. She graduated in Biochemistry Department at Ege University in Izmir Turkiye. She is currently research assistant and master degree student in Chemistry Department at Suleyman Demirel University in Isparta, Turkiye. Her research is focused on enzyme technology and microbial biotechnology.

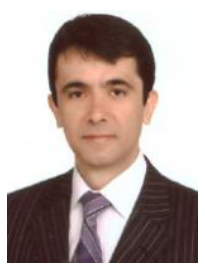

İsmail Ozmen was born at 1970. He works as professor, head of biochemistry section at Chemistry Department, at Suleyman Demirel University in Isparta, Turkiye. His researches are focused on technology and genetic of enzymes, fatty acid, antioxidant system, determination of mutation point of genetic illness and microbia biotechnology. 